\title{
Rapid voluntary clench induces bite force reflex in human
}

\author{
İnsanda hızlı istemli diş sıkma, 1sırma refleksi meydana getirir
}

Paulius UGINČIUS, Ričardas KUBILIUS, Edgaras STANKEVIČIUS

\begin{abstract}
Objective: The purpose of this study was to test the occlusal analysis system T-Scan II for the detection of a bite force reflex and to determine the net jaw reflex modulation during a rapid voluntary clench.
\end{abstract}

Materials and Methods: Eleven subjects were asked to bite as fast as possible on the pressure-sensitive sheet using occlusal scanning system T-Scan II. The bite force reflex parameters were determined from the occlusal force curve.

Results:The inhibitory bite force reflex occurred in nine subjects with a latency of $34.0 \pm 7.8 \mathrm{~ms}$, duration of $17.0 \pm 2.8 \mathrm{~ms}$ and strength of $1.6 \% \pm 0.3 \%$. A strong correlation was detected between the latency of the reflex and the time to reach $80 \%$ of the maximal relative bite force $(\mathrm{r}=0.833 ; \mathrm{p}<0.01)$. A moderate correlation was found between the relative bite force at the moment of the first turning point of the reflex and the change of this force during the reflex $(r=0.677 ; \mathrm{p}<0.05)$.

Conclusion: The reflex modulation confirms the protective role of the jaw reflex: during faster bites the latency of the bite force reflex was shorter and with a higher bite force the strength of the reflex was greater.

Keywords: Bite force reflex, Human, Occlusal scanning, Rapid voluntary clench, Relative bite force

Paulius Uginčius ( $₫)$, Edgaras Stankevičius

Institute of Physiology and Pharmacology, Lithuanian University of Health Sciences, Kaunas, Lithuania

e-mail: paulius.ugincius@lsmuni.lt

Ričardas Kubilius

Department of Oral and Maxillofacial Surgery, Hospital of Lithuanian University of Health Sciences Kauno Klinikos, Kaunas, Lithuania
ÖZET

Amaç: Bu çalışmada, 1sırma refleksi kuvvetini belirlemek için T-Scan II okluzal analiz sistemi kullanmak ve hızlı istemli diş sıkma sırasında net çene refleksindeki değişimi değerlendirmek amaçlanmıştır.

Gereç ve Yöntem : Çalışmamıza, 11 gönüllü denek katılmıştır. Denekler, T-Scan II okluzal analiz isteminin basınca duyarlı 1sırma sensörlerini 1sırabildikleri en hızlı şekilde 1sırmışlardır. Okluzal kuvvet eğrisi aracılığıyla 1sırma refleks parametreleri belirlenmiştir.

Bulgular: Onbir deneğin 9'unda inhibitor 1sırma refleksi tespit

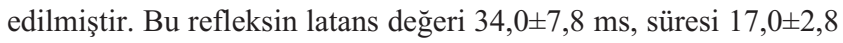

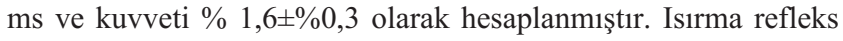
latans1 ile maksimum nispi 1sırma kuvvetinin \%80'ine ulaşmak için gereken zaman arasında güçlü bir ilişki gözlenmiştir $(r=0,833$; $\mathrm{p}<0,01)$. Isırma refleksinin ilk anındaki nispi 1sırma kuvveti ile bu kuvvetin refleks boyunca değişimi arasındaki ilişsi ise orta derecelidir $(\mathrm{r}=0,677$; $\mathrm{p}<0,05)$.

Sonuç: Isırma refleksindeki değişim, çene refleksinin koruyucu rolünü destekler. Hizlı 1sırma sırasında, kısa latansl bir 1sırma refleksi oluşur. Isırma kuvveti yükseldiğinde, refleksin kuvveti artar.

Anahtar kelimeler: Isırma refleksi, İnsan, Okluzal tarama, Hızlı istemli 1sırma, Nispi 1sırma kuvveti

\section{Introduction}

Mastication is one of the vital functions of mammals which involves high levels of bite force and a fine control of the jaw muscles. A disturbance in the fine control of mastication threatens the survival of the animal by producing extreme biting forces which lead to improper positioning of the teeth or to oral soft tissue loss. Therefore, the masticatory system is supplied with a number of afferent inputs coming from intra- and peri-oral structures and efferent outputs going to masticatory muscles [1]. The teeth are naturally equipped with extremely sensitive tactile sensors - periodontal mechanoreceptors (PMRs) [1,2]. PMRs provide information 
about tooth loads and they are located among the collagen fibers in the ligaments that attach the root of the tooth to the alveolar bone [3]. Tooth stimulation can also activate other vibration-, stretch-, and position- sensitive receptors in and around the jaws [4,5], and the vibration-sensitive receptors in the inner ear [6].

Reflex studies in which slowly rising mechanical stimuli were applied to the incisor teeth in an orthogonal direction suggested that, when subjects maintained a high activity of a masseter muscle, the output closing force was a net reduction whereas at low levels of background activity, the stimulus generates a net closing force [7]. Previous studies of jaw reflexes on humans using orthogonal fast-rising stimulation of teeth, i.e. mechanically stimulating the labial surface of the incisor $[1,4,8,9]$ or using normal tooth contact during mastication showed that the jaw-closing muscles are reflexly inhibited both in animals [10] and in humans [4,11].

Local anaesthetic blocks have been used to identify the reflex responses that originate from PMRs [4,12-14]. Several studies have illustrated that PMRs are responsible for the majority of the reflex responses of the human jaw muscles and that PMRs have much more powerful inhibitory effects on masseter muscles than previous suggestions [4,12-14].

In this study, we stimulated trigeminal receptors with the natural bite force. We preferred fast clench to find out if sharply built up bite force is interrupted by the jaw reflex and if it is possible to register this net bite force reflex response using clinical bite force detection system. The occlusal analysis system enabled us to determine the occluding teeth during bite force reflex and to involve the whole dental arch in eliciting the reflex.

The aim of the present study was to test the relevance of a routinely used computerized occlusal analysis system for detecting and estimating the change in the human bite force reflex. We aimed to determine whether there is the modulation of the bite force reflex during natural rapid voluntary clench.

\section{Materials and Methods}

This study was approved by the Kaunas region Biomedical Ethics Committee and all procedures used conformed to the Declaration of Helsinki. Participants were 11 consenting adult volunteers ( 3 females, 8 males) aged 20 to 31 years. All were neurologically normal with healthy dentitions and no history of craniomandibular dysfunction. The subjects were informed about the procedures and signed the informed consent forms.

\section{Protocol}

Subjects were seated comfortably and relaxed in a dental chair. A pressure-sensitive sheet of the occlusal analysis system was placed between the opposing dental arches with the distance of about $20 \mathrm{~mm}$ between the upper and lower incisors. The subject bit in intercuspal position as fast as possible and kept his/her position on the sheet till a computer confirmed the data were recorded. The scanning handle was kept as parallel to the occlusal plane of the subject as possible.

It is known that the teeth are displaced in their sockets following mechanical stimulation and successive taps do

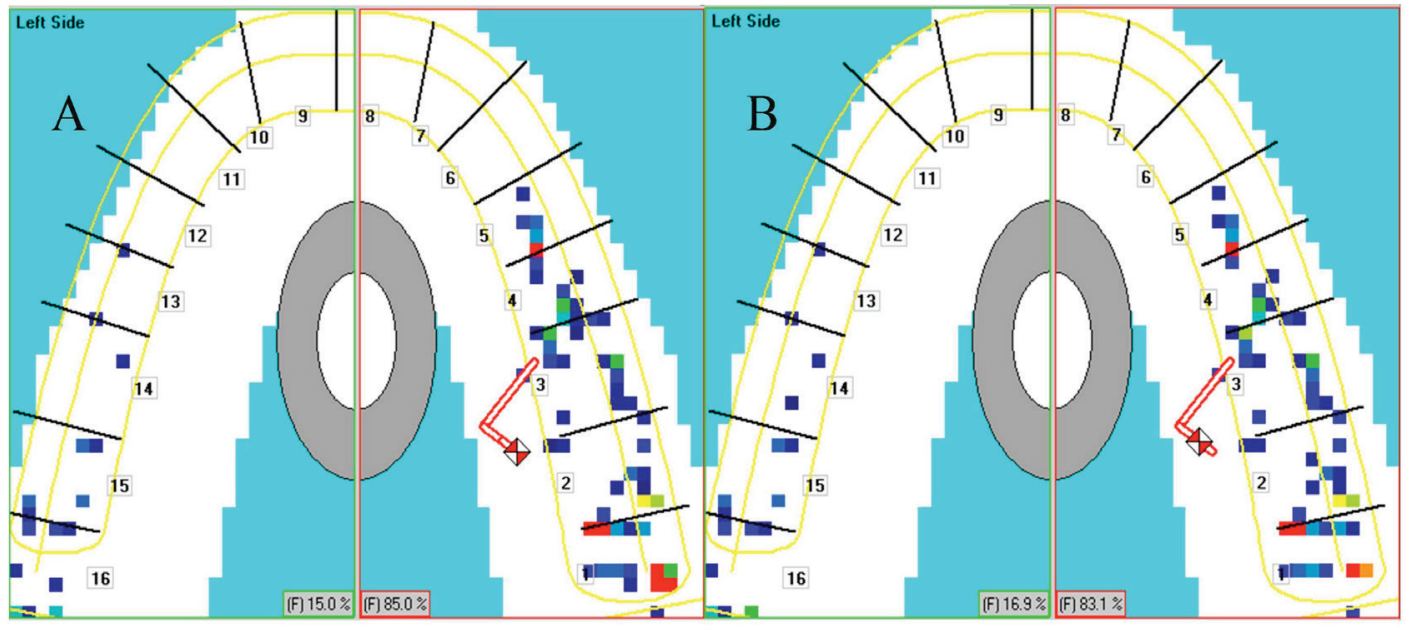

Colour coding of the relative bite force

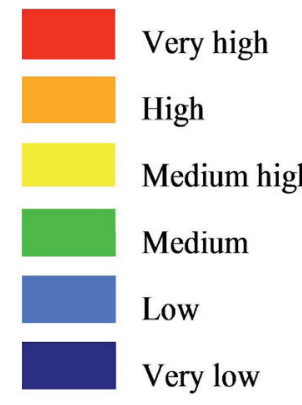

Figure 1. Occlusal scanning windows of a subject during fast clench into intercuspal position. The pressure of occluding teeth contacts at the moment of the first (A) and second (B) turning points of the bite force reflex shows a decrease of the bite activity of the right side in the area of the second molars. 
not permit them to return to their original position. In fact, the tooth is displaced during the first few taps by different amounts, only reaching a relatively stable position after a number of stimuli [15]. Therefore, the first 10 bites of subjects into intercuspal position were not included in the analysis to obtain a steady state response. In each trial, each subject bit five times with breaks lasted approximately $10 \mathrm{~s}$ between bites. Each trial was successful when the computer confirmed data after 3 to $5 \mathrm{~s}$ of recording procedure.

The computerized occlusal analysis system T-Scan II (Tekscan Inc., Boston, USA) which is fully non invasive was used in our study. This device senses and analyzes occlusal contact forces using paper-thin, disposable sheets, which include pressure-sensitive points, called sensels. Each sensel can be seen as a separate square in Fig 1. The system detects only relative bite force (RBF) values which are the values calculated from the maximal bite force during a single bite force scanning record. Red colour is the highest relative force value and blue colour is the lowest relative force value. The first tooth contact on the sheet will cause the system to begin recording a

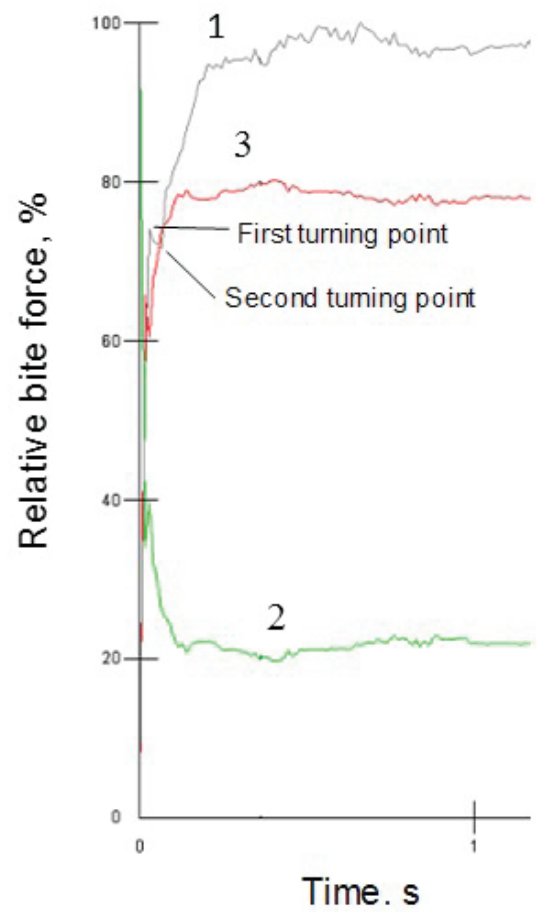

Figure 2. The relative bite force (RBF) graph of a subject during rapid voluntary clench. Curve (1) shows general RBF of both sides of dental arch. Curves (2) and (3) indicate forces generated by left and right sides of the dental arch, respectively. At the very beginning of the recording [see curve (1) only] a bite force reflex appears, which is composed of the first and the second turning points.
RBF. Once recording is complete, a graph (Fig 2) of the general RBF [curve (1)] and the graph of the RBF of left [curve (2)] and right [curve (3)] sides of a dental arch are displayed. The general RBF [curve (1)] is analysed only in this study.

The characteristics of the detected bite force reflex [Fig 2, curve (1)] were as follows: the latency (the time from the beginning of the built up bite force till the first turning point of the reflex), duration (includes the time between the first and the second turning points), and strength; the RBF during the first and the second turning points of the reflex, and the time to reach $80 \%$ of maximal RBF during sudden voluntary clench into intercuspal position.

\section{Statistics}

Averages and mean square errors of the bite force reflex characteristics were detected. Also coefficients of correlation and error probabilities between the latency of the reflex and the time to reach $80 \%$ of maximal RBF during fast voluntary jaw closing into intercuspal position, and between the RBF during the first turning point and the strength of the reflex were determined. The level of significance was set at $\mathrm{p}<0.05$.

\section{Results}

The fast bite into intercuspal position generated a decrease followed by an increase in bite force until the maximal RBF value was established (Fig 2). The occlusal pressure of some sensels decreased after the first turning point of the RBF during the reflex (it is clearly seen on the right side in the molar region in Fig 1 [compare (A) and (B)].

The bite force reflex response was observed in nine subjects out of 11 but not during every experimental bite or trial. The latency of the bite force reflex was $34.0 \pm 7.8$ $\mathrm{ms}(\mathrm{n}=9)$. The latency represents the time from the first teeth contact till the first turning point of the reflex change in bite force. The duration and the strength of the change in bite force during the reflex was $17.0 \pm 2.8 \mathrm{~ms}$ and $1.6 \% \pm$ $0.3 \%$, respectively $(n=9)$. The jaw reflex was determined between 40 and $90 \%$ of RBF values in 6 cases, between 20 and $40 \%$ of RBF values in one case, and between 0 and $20 \%$ of RBF values in two cases. Bite force reflex response was not observed in two subjects even after five sets of trials.

The time to reach $80 \%$ of maximal RBF during fast voluntary clench was $151.0 \pm 27.4 \mathrm{~ms}(\mathrm{n}=11)$. This value of the RBF was selected because after this bite level the RBF slows the rapid increase dramatically (Fig 2).

A strong correlation was detected between the latency of 
the bite force reflex and the time to reach $80 \%$ of maximal RBF during fast voluntary clench $(r=0.833, p=0.005)$.

A moderate correlation was detected between the RBF during the first turning point of the reflex and the reflex strength $(r=0.677, p=0.045)$.

\section{Discussion}

The stimulus we used in this study was a natural teeth contact occurring during sudden jaw clench. Therefore, bite force reflex was elicited in experimental conditions which were very close to the natural ones.

The results of the current study show that the main form of feedback to the jaw muscles during rapid voluntary clench is a net bite force inhibition. The force output is generated by a group of jaw muscles, hence the bite force decrease is a net inhibition of the motoneuronal pool of all jaw muscles [7]. Therefore electromyogram of masseter or temporalis muscle can, however, complement the bite force record, but cannot be used for indirect evaluation of the bite force [16].

Our results also suggest that the bite force reflex latency becomes longer with the longer time to reach $80 \%$ of maximal RBF. The RBF is not only increased by a common excitatory drive during voluntary jaw muscle contraction, but also is the source of a trigeminal stimulation. It might be that the initiation of the bite force reflex depends on the stimulation rate of the trigeminal receptors. That is, the fast bite force rate elicits reflex response with shorter latency, while the slow bite force rate induces longer latency inhibition. The nature of the resulting feedback is unclear due to the difficulty in stimulating the PMRs without activating other receptors in the perioral region at the same time. Mechanical stimuli activate a number of receptors that may have different synaptic connections to the motoneuronal pool of the masticatory muscles [1]. Nevertheless, most likely, that the bite force reflex is regulated by a periodontal feedback to protect the masticatory system from being damaged, as it has been confirmed that PMRs significantly contribute to the inhibition of jaw-closers $[1,4,8,9,12,14,17,18]$.

These results further highlight the importance of the RBF value for the modulation of the strength of the jaw reflex; as we found that the higher RBF values produced stronger net inhibitory reflex.

Both the faster bite force rate and the bigger RBF signal to a jaw-brake system about an overloading of the masticatory system. The jaw-brake system detects this potential danger via trigeminal receptors (especially PMRs) and reduces the latency of the inhibition during faster bite force increase; also it increases the strength of inhibition for higher RBF values. The protective role of the jaw reflex helps for masticatory system to prevent the damage of a periodontium, dental tissues, and surrounding structures of the mouth.

The latency and the duration of the bite force reflex response in this study have similar characteristics as found in other studies, which used a single-tooth stimulation procedure $[1,8,13,14,17]$. Previously it was found that the average latency of the bite force decrease when an incisor was stimulated axially was about $33 \mathrm{~ms}$ and the average duration of the change in bite force due to the medium and fast stimuli was $18 \mathrm{~ms}$ [13]. The average electromyogram/ force delay of $16 \mathrm{~ms}$ was established in the same study. The inhibitory responses of the electrical activity of the masseter muscle have a mean latency of $11-13 \mathrm{~ms}[8,19]$ and a mean duration of $18 \mathrm{~ms}$ [19]. Türker and Jenkins reported that a minimal inhibitory latency of the masseter muscle was about $20 \mathrm{~ms}$ and the latency for the reduction in the bite force was $28 \mathrm{~ms}$ [13]. Therefore, even though the teeth in both dental arches were stimulated, the characteristics of the reflex are similar to the ones during single-tooth stimulation studies.

$\mathrm{Yu}$ et al. found that the higher level of muscle activity maintained by the subject markedly reduced both the incidence and the duration of the inhibition produced by innocuous and noxious stimuli of intraoral and facial regions [20]. This finding may explain why in our study the bite force reflex did not manifest in every trial. Likewise, the decrease in bite force cannot be elastic recoil, because the decrease did not appear in every rapid bite and in all the subjects. Also, the reaction of a subject as the consequence of the decrease in bite force must be rejected, because the minimum reaction time was found to be $150 \mathrm{~ms}$ for the bite force when axial stimulus to a tooth was used [21], whereas we found that the latency of the bite force reflex is about 34 ms. Therefore, it is hardly possible that the biphasic change in the RBF during fast voluntary clench registered using $\mathrm{T}$-Scan II system is an artifact.

There were large inter-subject differences found in almost all reflex statistics measured. This finding is also confirmed by other studies [17]. While age was tightly controlled (only young subjects were tested) other subject factors may have contributed to this controversy. These factors may include, but are not limited to: periodontal health, tooth crowding, tooth angle, recent tooth usage, periodontal history and the amount of $\gamma$-motoneurone activity [17,21]. While every effort was made to ensure subjects had healthy teeth and gums with no history of orthodontic treatment or periodontal disease, some subject differences were unavoidable. 


\section{Conclusions}

T-Scan II system is capable in estimating physiological characteristics of the bite force reflex during sudden voluntary clench in humans. The net inhibition of masticatory muscles induced by sudden voluntary clench is very powerful as it clearly reflects on a record by using clinical occlusal analysis system.

When using faster clench into intercuspal position which signal more dangerous impact to the oral tissues, the latency of a reflexive decrease in bite force is shorter and the strength of this force decrease is bigger as this is what matters for the organism. During a fast clench, the net response from all the jaw-closers may show the power of the trigeminal receptor input to the jaw-closing muscles.

Clinically it is important to understand the source of the modulation of the bite force and how the bite force rate and strength change the activity of jaw muscles.

\section{Acknowledgements}

We would like to acknowledge Gizem Yılmaz at Koç University School of Medicine, Turkey, for linguistic revision of the manuscript.

\section{References}

1. Türker KS. Reflex control of human jaw muscles. Crit Rev Oral Biol Med 2002; 13: 85-104.

2. Trulsson M. Sensory-motor function of human periodontal mechanoreceptors. J Oral Rehabil 2006; 33: 262-73. doi: 10.1111/j.1365-2842.2006.01629.x.

3. Lambrichts I, Creemers J, van Steenberghe D. Morphology of neural endings in the human periodontal ligament: an electron microscopic study. J Periodontal Res 1992; 27: 191-6.

4. Uginčius P, Atiş ES, Türker KS. Reflex responses of human masseter motor units to mechanical stimulation of the teeth. J Neurophysiol 2014; 111: 51-61. doi: 10.1152/jn.00478.2013.

5. Lund JP. Mastication and its control by the brain stem. Crit Rew Oral Biol Med 1991; 2: 33-64. doi: 10.1177/10454411910020010401.

6. Meier-Ewert K, Gleitsmann K, Reiter F. Acoustic jaw reflex in man: its relationship to other brain-stem and microreflexes. Electroencephalogr Clin Neurophysiol 1974; 36: 629-37.

7. Yang J, Türker KS. Jaw reflexes evoked by mechanical stimulation of teeth in humans. J Neurophysiol 1999; 81: 215663.

8. Brodin P, Türker KS, Miles TS. Mechanoreceptors around the tooth evoke inhibitory and excitatory reflexes in the human masseter muscle. J Physiol 1993; 464: 711-23. doi: 10.1113/ jphysiol.1993.sp019659.

9. Türker KS, Sowman PF, Tuncer M, Tucker KJ, Brinkworth RSA. The role of periodontal mechanoreceptors in mastication. Arch Oral Biol 2007; 52: 361-4. doi:10.1016/j. archoralbio.2006.11.014

10. Thomas NR, Peyton SC. Relationship of masseter electromyographic activity to mandible position in the freelymoving rat. Arch Oral Biol 1983; 28: 1043-6.

11. Ahlgren J. The silent period in the EMG of the jaw muscles during mastication and its relationship to tooth contact. Acts Odontol Scand 1969; 27: 219-27.

12. Sessle BJ, Schmitt A. Effects of controlled tooth stimulation of jaw muscle activity in man. Arch Oral Biol 1972; 17: 1597607.

13. Türker KS, Jenkins M. Reflex responses induced by tooth unloading. J Neurophysiol 2000; 84: 1088-92.

14. Besset RW, Mohl ND, Bishop B. Contribution of periodontal receptors to the masseteric silent period. J Dent Res 1976; 53 : 1196-203.

15. Moxham BJ, Berkovitz BKB. The effects of external forces on the periodontal ligament. In: Berkovitz BKB, editor. The Periodontal Ligament in Health and Disease. 2nd ed. London: Mosby-Wolfe, 1995: 215-41.

16. Brinkworth RSA, Türker KS. A method for quantifying reflex responses from intra-muscular and surface electromyogram. J Neurosci Methods 2003; 122: 179-93. doi:10.1016/S01650270(02)00321-7.

17. Brinkworth RSA, Türker KS, Savundra AW. Response of human jaw muscles to axial stimulation of the incisor. J Physiol 2003; 547: 233-45. doi: 10.1111/j..2002.00233.x.

18. Hannam AG. Changes in the activity of the masseter muscle following tooth contact in man. Arch Oral Biol 1969; 14: 14016.

19. Mason AG, Scott BJ, van der Glas HW, Linden RW, Cadden SW. Remote noxious stimuli modulate jaw reflexes evoked by activation of periodontal ligament mechanoreceptors in man. Exp Physiol 2002; 87: 699-706. doi: 10.1113/eph8702452.

20. Yu SKJ, Schmitt A, Sessle BJ. Inhibitory effects on jaw muscle activity of innocuous and noxious stimulation of facial and intraoral sites in man. Arch Oral Biol 1973; 18: 861-70. doi: doi:10.1016/0003-9969(73)90056-3.

21. Brinkworth RSA, Türker KS. EMG, force and discharge rate analysis of human jaw reflexes in response to axial stimulation of the incisor. Exp Brain Res 2005; 161: 145-54. doi: 10.1007/ s00221-004-2053-4.

22. Garcia Cartagena A, Gonzalez Sequeros O, Carrido Garcia VC. Analysis of two methods for occlusal contact registration with the T-scan system. J Oral Rehab 1997; 24: 426-32. doi: 10.1111/1365-2842.ep14748221.

23. Kohyama K, Hatakeyama E, Sasaki T, Azuma T, Karita K. Effect of sample thickness on bite force studied with a multiple-point sheet sensor. J Oral Rehab 2004; 31: 327-34. doi: 10.1046/j.1365-2842.2003.01248.x.

24. Trulsson M. Force encoding by human periodontal mechanoreceptors during mastication. Arch Oral Biol 2007; 52: 357-60. doi: 10.1016/j.archoralbio.2006.09.011.

25. Kawamura Y. Recent concepts of the physiology of mastication. In: Staple PH, editor. Advances in Oral Biology. Vol. 1. London: Academic Press, 1964: 77-109. 